\title{
PREVENTION OF WATER POLLUTION CAUSED BY NITRATES FROM AGRICULTURE IN SERBIA
}

\author{
Predrag Vuković ${ }^{1}$, Vesna Popović ${ }^{2}$,Jonel Subić3 , Nataša Kljajićc \\ *Corresponding author E-mail: predrag_v@iep.bg.ac.rs
}

\begin{abstract}
A R T I C L E I N F O
A B S T R A C T

Original Article

Received: 23 January 2018

Accepted: 28 July 2018

Knowledge of agricultural soil vulnerability to water and nitrogen losses is essential for designing management guidelines to minimize water pollution from agriculture. Here, the authors presented the results of assessing the doi:10.5937/ekoPolj1803895V

UDC 628.515:338.43(497.11)

Keywords:

nitrates, agriculture, water pollution, LOS indices, vulnerability map, nitrogen BMPs

JEL: Q15, Q53,Q58 intrinsic vulnerability of agricultural soil of the City of Pančevo (Serbia) to water and nitrogen losses using LOS indices method. As the most vulnerable, the indices, presented in the form of vulnerability maps, marked the northeast part of the City of Pančevo area, including part of Deliblato Sands. Determined closed periods for use of fertilizers, rules for soil application and balanced fertilization, optimized production structure and irrigation methods, application of contour ploughing and conservation tillage and maintenance of buffer strips are among the priority nitrogen best management practices (BMPs) for agriculture and water protection. Well-tailored, site-specific nitrogen BMPs based on the LOS analysis can significantly improve compliance with EU Nitrate Directive, which transposition is ongoing in Serbia.
\end{abstract}

(C) 2018 EA. All rights reserved.

\section{Introduction}

Water pollution by nutrients (nitrogen and phosphorus) have accelerated the rate and extent of natural process of surface waters eutrophication, which is characterized

1 Predrag Vuković, Ph.D, Research associate, Institute of Agricultural Economics, Belgrade, Volgina st. No.15, Belgrade, Serbia +381 11 697-2858, e-mail: predrag_v@,iep.bg.ac.rs, ORCID ID (https://orcid.org/0000-0002-4723-9815).

2 Vesna Popović, Ph.D, Principal Research Fellow, Institute of Agricultural Economics, Belgrade, Volgina st. No.15, +381 116972854 , e-mail: vesna p@iep.bg.ac.rs, ORCID ID (https://orcid.org/0000-0003-1018-2461).

3 Jonel Subić, Ph. D. Senior Research Associate, Institute of Agricultural Economics, Belgrade, Volgina St. No.15, 11060 Belgrade, +381 11697 2858, e-mail: jonel_s@iep. bg.ac.rs, ORCID ID (https://orcid.org/0000-0003-1342-1325).

4 Nataša Kljajić, Ph.D. Research associate, Institute of Agricultural Economics, Belgrade, Volgina st. No.15, Belgrade, Serbia +381 1169728 58, e-mail: natasa_k@iep.bg.ac.rs, ORCID ID (https://orcid.org/0000-0003-2245-8285).

http://ea.bg.ac.rs 
by harmful algal (including cyanobacterial) blooms (HABs), oxygen depletion and toxicity (Schindler, 1974; Smith, Schindler, 2009; Paerl et al., 2011; Paerl, Paul, 2012; Chislock et al., 2013).

Increased stream nitrate $\left(\mathrm{NO}_{3}^{-}\right)$loading stimulates denitrification and concomitant nitrous oxide $\left(\mathrm{N}_{2} \mathrm{O}\right.$ ) production ${ }^{5}$ (Beaulieu et al., 2011). Nitrate is also the most ubiquitous chemical contaminant in the world's aquifers (Spalding, Exner, 1993). Shallow groundwater is particularly susceptible to nitrate contamination (Nolan et al., 2002).

These phenomena severely deteriorate water quality and ecosystem functioning and impair the use of water for drinking, agriculture, industry, recreation and other purposes (Carpenter et al., 1998). $\mathrm{NO}_{3}^{-}$in water is toxic at high concentrations, has been linked to methemoglobinemia in infants and has shown toxic effects on livestock (Sandstedt 1990; Amdur et al., 1991).

Extensive use of nitrogen fertilizers and livestock manure in crop production is the largest diffuse source of pollution by nitrates, affecting surface and groundwater quality (Bouraoui et al., 2009; Haller et al., 2013). Agricultural point source of pollution by nitrates is related to improper management and safety practices in intensive livestock farming (Osterberg, Wallinga, 2004; Sahoo et al., 2016).

Prevention of nitrate pollution from croplands depends on increased nitrogen use efficiency $^{6}$, particularly on reduction of post-harvest soil nitrate content. Prevention of point source pollution on livestock farms is related to proper manure storage and maintenance of livestock facilities.

The EU Nitrates Directive (ND), as an integral part of the Water Framework Directive $(91 / 676 / \mathrm{EEC})$, is one of the key instruments in the protection of waters against nitrate pollution from agriculture.

The latest ND implementation assessments have documented the EU water quality improvement regarding nitrate concentrations. Based on annual averages of all reported fresh surface water monitoring stations in EU-27 in 2008-2011, 62.5\% were below 10 $\mathrm{mg} / \mathrm{l}$ of nitrate $\left(\mathrm{NO}_{3}^{-}\right), 2.4 \%$ showed concentrations between 40 and $50 \mathrm{mg} / 1$ and $2.4 \%$ exceeded $50 \mathrm{mg} / 1$. Regarding groundwater, $14.4 \%$ of groundwater stations exceeded 50 $\mathrm{mg} / \mathrm{l}$ of nitrate $\left(\mathrm{NO}_{3}^{-}\right)$and $5.9 \%$ were between 40 and $50 \mathrm{mg}$. It is in both cases a slight improvement over the previous reporting period (EC, 2013).

The pressure from agriculture has decreased regarding the consumption of chemical fertilizers and livestock number, but some hotspots related to manure storage and

$5 \quad \mathrm{~N}_{2} \mathrm{O}$ is a greenhouse gas that contributes to climate change and stratospheric ozone depletion. Using a global river network model, Beaulieu et al. (2010) estimate that microbial $\mathrm{N}$ transformations (e.g. denitrification and nitrification) convert anthropogenic $\mathrm{N}$ inputs to $\mathrm{N}_{2} \mathrm{O}$ in rivers; this process leads to $10 \%$ of the global anthropogenic $\mathrm{N}_{2} \mathrm{O}$ emission.

6 The ratio of $\mathrm{N}$ removed in the harvest to the $\mathrm{N}$ inputs from fertilizers, manures, $\mathrm{N}$ fixation, and other amendments (Davidson et al., 2015). 
intensive horticultural production and associated with soil and geological formations (e.g. sandy and loess soils, as well as karstic and other porous rocks), have not been sufficiently addressed and require additional measures or reinforced actions.

According to the Nitrates indicator, ${ }^{7}$ monitored in Serbia since 2004, the quality of surface water has constantly improved during 2008-2013. Median values ranged from 0.5-2 $\mathrm{mg} / 1 \mathrm{NO}_{3}-\mathrm{N}$, corresponding to a good ecological status. Unfavorable (increasing) trend of nitrates was observed on 3 out of 56 measuring points. The quality of groundwater is monitored since 2004 at 29 measuring points. The quality of groundwater has constantly improved in the period 2009-2013. Excessive concentration, greater than 50 $\mathrm{mg} / \mathrm{NO}_{3}$, , was observed at one measuring point with favorable (decreasing) trend. In 2013, the concentration of $25 \mathrm{mg} / \mathrm{l}$ was not exceeded and in this year the quality was the best for the whole observed period 2004-2013 (SEPA, 2015).

Agricultural activities have a principal role in the generation of nitrogen emission in the Danube basin. The agricultural pressure could strengthen due to the expected stronger agriculture development in the future, especially in the middle and lower parts of the Danube. The non-EU ICPDR countries (including Serbia) are highly encouraged to implement best agricultural practices, similar to those required by the EU ND in the EU Member States (ICPDR, 2015). The largest source of nitrate pollution in the Danube basin in Serbia is overland flows ${ }^{8}$ (56\% of total annual nitrogen loads) and livestock, with a share of $26 \%$ (MAEP, 2014a).

Nitrogen cycling in soil is extremely dynamic and complex, especially the microbiological processes responsible for mineralization, fixation and denitrification of soil nitrogen (Ongley, 1996). Soluble and mobile, nitrate is prone to leaching through soil with percolated water. $\mathrm{NO}_{3}{ }^{-}$is also observed in surface runoff during rainfall events. The key hydrological processes that link precipitation, surface runoff and leaching have a decisive role in nitrate fate and transport (Ongley, 1996; Nolan et al., 2002; Böhlke, 2002; Van Drecht et al., 2003; Seitzinger et al., 2006; Leone et al., 2009; Puckett et al., 2011; Welch et al., 2011).

Nitrogen fate and transport modeling is essential in analyzing $\mathrm{N}$ flows and designing management guidelines to minimize surface and groundwater pollution. For nonpoint sources, spatial information on land use, climate, hydrology, geology and soils are combined with data on $\mathrm{N}$ inputs and outputs (Van Drecht et al., 2003). Nitrogen loads, transformation and transport also depends on different agricultural practices, including the ones related to crop types and crop rotation, soil tillage and residue management, irrigation and drainage techniques and use of various nitrogen fertilizers (Seitzinger et al., 2006; Aschonitis et al., 2013).

7 The indicator monitors the concentration of nitrate in rivers $\left(\mathrm{NO}_{3}-\mathrm{N}\right) /$ groundwater $\left(\mathrm{NO}_{3}^{-}\right)$ and is calculated as the median of a range of average annual value of nitrate measured at measuring points. The existence and intensity of trend assessment is determined by Mann Kendall test and Sen'S non-parametric method.

8 Total CORINE land areas flows.

http://ea.bg.ac.rs 
According to ND Annex 1, in applying the criteria for identification of polluted waters or waters at risk of pollution, it is necessary to take into account, inter alia, the physical and environmental characteristics of the waters and land as well as the current understanding of the behavior of nitrogen compounds in the water and soil.

The LOS indices methodology is developed in order to classify the vulnerability of agricultural land to water and nitrogen $\operatorname{losses}^{9}$. The indices were developed by multiple regression analysis using the GLEAMS v3.0 model $^{10}$ simulations for the reference field crop under various soil physical-hydraulic and biochemical properties, topography and climatic conditions as observed values (Aschonitis et al., 2012).

The indices were presented in GIS environment (vulnerability maps). The spatial integration of vulnerability maps in the decision support systems enables regional authorities to design policies for optimal agricultural development and water protection from the agricultural land uses (Manos et al., 2010; Aschonitis, Mastrocicco, 2017).

By signing the Stabilization and Accession Agreement (SAA), Serbia committed to gradual harmonization of domestic legislation with the acquis communautaire. The identification of agricultural lands with significant contribution to $\mathrm{N}$ pollution, delineation of these zones and a catalogization of best agricultural practices to control nitrate pollution are the main tasks within the EU ND transposition.

The LOS indices application, presented here, can considerably improve the results of these activities and the main aim of the paper is to contribute to this efforts. The results of assessing the vulnerability of agricultural land to water and nitrogen losses using LOS indices in the City of Pančevo (Serbia), presented in the following chapter, ${ }^{11}$ enabled the authors to designate and suggest well-tailored, site-specific best management practices to control water pollution by nitrates from agriculture.

9 The most accurate methods to determine water and nitrogen losses from agricultural land are the process-based mathematical models but they require a high amount of (usually lacking) data while vulnerability indices use fewer and more accessible data but are based on subjective weights and rating. LOS indices, calibrated by regression analysis based on the results of the deterministic GLEAMS model, belong to combined methods (Aschonitis et al., 2012; Aschonitis et al., 2013; Aschonitis et al., 2016; Aschonitis, Mastrocicco, 2017).

10 GLEAMS (Groundwater Loading Effects of Agricultural Management Systems) is a process-based mathematical model developed for field crop areas to simulate the surface and bottom of root zone loadings of water, sediment, pesticide and plant nutrients deriving from different climate, soil and agricultural management interactions (Leonard et al., 1987; Knisel, Davis, 2000).

11 LOS method (Aschonitis et al., 2012), as well as the above-mentioned case study research (Cvijanović et al., 2012) were developed within the EU project EU.WATER Transnational Integrated Management of Water Resources in Agriculture for the European Water Emergency Control (2010-2012) (Arampatzis et al., 2012). 


\section{Materials and methods}

To classify the intrinsic vulnerability of the topsoil $(30 \mathrm{~cm})$ to water and nitrogen losses via percolation and runoff and to develop the related vulnerability maps for agricultural land of the City of Pančevo (Serbia), the following LOS indices were used:

- LOSW-P (annual intrinsic rates of water losses through percolation, in mm year $\left.^{-1}\right)$,

- LOSW-R (annual intrinsic rates of water losses through surface runoff, in mm year $\left.^{-1}\right)$,

- LOSN-PN (annual intrinsic rates of nitrogen losses through percolation, in kg-N ha ${ }^{-1}$ year $^{-1}$ ) and

- LOSN-RN (annual intrinsic rates of nitrogen losses through surface runoff, in kg-N ha ${ }^{-1}$ year $\left.^{-1}\right)$.

The sum of total losses of water (LOSW-PR) is calculated as the sum of the total losses of water through percolation (LOSW-P) and surface runoff (LOSW-R) and the sum of total losses of nitrogen (LOSN-PRN) is calculated as the sum of the total losses of nitrogen through percolation (LOSN-PN) and surface runoff (LOSN-RN) (Aschonitis et al., 2012).

Regarding the topography of the study area, analyses were conducted using the Digital Elevation Model acquired from SRTM data (NASA Shuttle Radar Topographic Mission $90 \mathrm{~m}$ Digital Elevation Data) in raster format. Hydrometeorological data were provided by the Pančevo meterological station, Faculty of Natural Sciences, Novi Sad and meteorological station of the PDS Institute "TAMIŠ," Pančevo. PDS Institute "TAMIŠ" was the source of soil properties data, soil and water quality analysis and data on irrigation and fertilization practices while the main hydrologic data were provided by Pančevo water level station.

\section{Study area}

The city of Pančevo is located in the Republic of Serbia, in the south-west Banat, within the rivers Danube, Tamiš and Nadela and covers an area of $756 \mathrm{~km}^{2}$ with 123,414 inhabitants. ${ }^{12}$ As a consequence of intensive production and obsolete technologies in oil, chemical and petrochemical, starch, leather and food industry, Pančevo has been designated as environmental hot-spot in Serbia.

The mean annual temperature in this area is $11.3{ }^{\circ} \mathrm{C}$ while the average annual precipitation has a value of $643 \mathrm{~mm}$, with two maximums - from the end of spring to early summer and from the end of autumn to early winter. Reference values for potential evapotranspiration are in the range of $689-715 \mathrm{~mm}$.

122011 Census data (SORS, 2014).

http://ea.bg.ac.rs 
As a part of the Pannonian Basin, the territory of Pančevo City has a low elevation and a mostly flat surface, gently sloping from northeast to southwest and in the direction of Tamiš and Danube river flows. There are three geomorphological units: 1) loess plateau (with an average altitude of 100 to $150 \mathrm{~m}$ above sea level), 2) loess terrace (75 - $83 \mathrm{~m}$ a.s.1.) and 3) alluvial plain (70 - $73 \mathrm{~m}$ a.s.1.). Carbonate and sandy chernozems cover $70.5 \%$ of the City territory, humogleys $14.3 \%$, fluvisols $9.7 \%$, semigleys $4.3 \%$ and alkaline soil (solonetz) 1.2\%.

Surface waters consist of rivers Danube, Tamiš, Nadela and Ponjavica and the network of melioration canals. ${ }^{13}$ Groundwater encompasses shallow (phreatic) and deep (artesian) water-bearing layers. The phreatic layer is thinnest in the alluvial plains where it ranges from 1 to $2 \mathrm{~m}$, while at loess plateau reaches $15-20 \mathrm{~m}$ (30 m in certain localities). The artesian groundwater is found at greater depths, which makes it highly mineralized. Limited reserves of good-quality deep groundwater have been located at the edges of loess plateau and Deliblato Sands.

Utilized agricultural area ${ }^{14}$ (UAA) occupies 53,187 ha of the City territory (70.4\%), of which kitchen gardens cover $0.4 \%$ of UAA, arable land $97.8 \%$, orchards (apples, apricots, cherries, peaches) $0.9 \%$, vineyards $0.1 \%$ and meadow and pastures $0.6 \%$. Large farms, with more than 20 ha of UAA ( $8 \%$ of the total number of farms with UAA) use $67.6 \%$ of total UAA.

In $2011 / 2012$ crop year ${ }^{15}, 70.8 \%$ of arable land was engaged in cereals production (maize, wheat), 23.2\% was covered with oilseeds (sunflower, soya), 2.6\% with sugar beet and $2.3 \%$ with fodder crops. Vegetables (cabbage, sweet pepper), melons and strawberries occupied $0.4 \%$ of arable land as well as medicinal herbs. The potato fields covered $0.2 \%$ of UAA.

The production and yields in rain fed crop farming have strong yearly oscillations, mostly due to more frequent and longer draught periods. Irrigation systems are underdeveloped and despite the high availability of water, irrigation is applied sporadically to very limited area, mostly under maize and other cereals, vegetables, ${ }^{16}$ melons and strawberries and potatoes.

In $2011 / 2012$ crop year, conventional tillage was used on 46,943 ha $(91.8 \%$ of arable land ${ }^{17}$ ), reduced tillage on $8.0 \%$, and zero tillage on $0.2 \%$. More than $90 \%$ of arable land was in crop rotation. Winter crops were sown on 8,309 ha ( $16 \%$ of arable land) and cover crops only on 11 ha. Crop residue mulch was applied on 2,417 ha (5\%). Bare soils covered $79 \%$ of arable land area. Less than $2 \%$ of agricultural holdings with UAA

13 Alluvial terrains are vulnerable to high groundwater after the construction of Iron Gate hydroelectric power plant.

142012 Census of Agriculture data (SORS, 2015).

15 Ibid.

16 In vegetable production drip irrigation amounts to 200 - $400 \mathrm{~mm}$ (PDS “Tamiš” data).

17 Arable land producing crops requiring annual replanting, without greenhouses. 
built and/or maintained hedges, hedgerow trees and dry stone walls as field margins in the three-year period preceding the 2012 Census (SORS, 2015).

According to 2012 Census of Agriculture data, livestock production is poorly developed, but the livestock farm capacities are growing. There were 5,504 heads on 363 farms in cattle breeding of which only seven farms had 3,943 cattle. In pig production, 42,917 pigs were bred on 3,584 farms but nearly half of them were bred on four large pig farms. A total of 340,195 heads of poultry was bred on 4,044 farms. More than half of this number was in flocks of six large producers.

The largest number of farms that stored solid manure solely stockpiled it $(96.8 \%), 1.7 \%$ owned stacking pads (exposed $0.5 \%$ and roofed $1.2 \%$ ), and $1.5 \%$ used both solutions. A small number of farms stored liquid manure and slurry, mainly in open lagoons and tanks (SORS, 2015).

The consumption of nitrogen fertilizers (in nutrient per hectare of arable land and permanent crops) in the Republic of Serbia has recovered since the nineties and, according to 2014 FAO Statistical Yearbook data, in 2009 amounted to $91 \mathrm{~kg} / \mathrm{ha} .{ }^{18}$

In the City of Pančevo, nitrogen fertilizers were used in the range of $80 \mathrm{~kg}-\mathrm{N} / \mathrm{ha} /$ year (sunflower) up to $140 \mathrm{~kg}-\mathrm{N} / \mathrm{ha} /$ year (maize, sugar beet), in two applications (for sunflower one application) (PDS “Tamiš" data).

Soil and water quality tests, realized during EU.WATER Project (2010-2012), showed that land was in the categories ${ }^{19}$ of well supplied with nitrogen up to reach in nitrogen, while nitrate content in waters was in the range of $0.58-0.85 \mathrm{mg} / 1 \mathrm{NO}_{3}-\mathrm{N}$, far below the limits established in national regulations (Cvijanović et al., 2012).

\section{Results and discussion}

LOSW indices, applicated in the City of Pančevo case study, showed that the water losses through percolation under the root zone of the $30 \mathrm{~cm}$ of soil profile (LOSW-P) are lower for agricultural land near the river, where alluvial soils dominate, and increase moving to the east to the Deliblato Sands, due to the transition from alluvial soils to sandy chernozem.

Water losses through surface runoff (LOSW-R) are higher at the western part of the area due to higher slopes while the medium values are registered in its central parts due to the low hydraulic conductivity (Cvijanović et al., 2012).

Regarding the total water losses (LOSW-PR), the eastern zone, along the edges of Deliblato Sands is designated as the most vulnerable (Figure 1).

18 The heaviest nitrogen fertilizer user in the EU-27 in 2009 was Ireland ( $332 \mathrm{~kg} / \mathrm{ha})$, followed by Luxembourg $(211 \mathrm{~kg} / \mathrm{ha})$ and the Netherlands $(206 \mathrm{~kg} / \mathrm{ha})$. Other heavy user of nitrogen fertilizers was Croatia (184 kg/ha) (FAO, 2014).

19 By Wohltmann (Džamić, 1966).

http://ea.bg.ac.rs 
Figure 1. Annual total water losses from agricultural land in the City of Pančevo, the Republic of Serbia

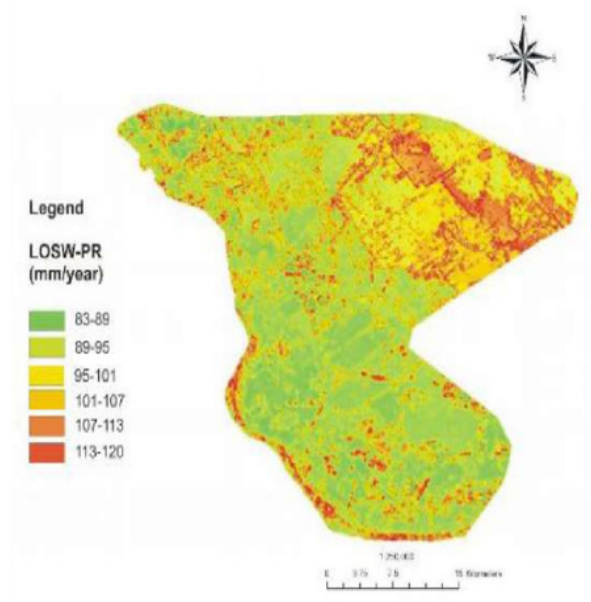

Source: Arampatzis et al., 2012.

As in the case of water, nitrogen losses through percolation under the root zone of the $30 \mathrm{~cm}$ of soil profile (LOSN-PN) are lower at the Danube riverbank area and increase moving to the east due to the transition from fine texture, alluvial soils with low hydraulic conductivity to coarser, sandy soils with higher hydraulic conductivity. The distribution of nitrogen losses through surface runoff (LOSN-RN) is analogous to LOSW-R (Cvijanović et al., 2012). Regarding the total nitrogen losses (LOSN-PRN), the most vulnerable zone is detected upland in the northeastern area (Figure 2).

Figure 2. Annual total nitrogen losses from agricultural land in the City of Pančevo, the Republic of Serbia

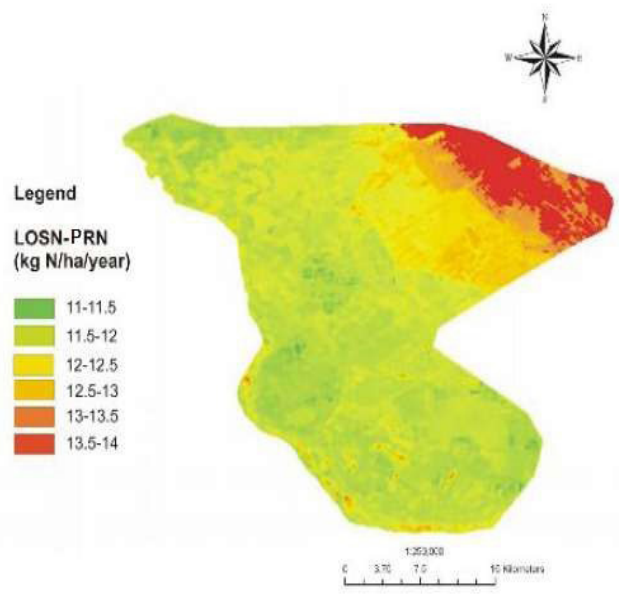

Source: Arampatzis et al., 2012. 
Considering the above, the northeast part of the City of Pančevo area, which includes part of Deliblato Sands, is identified as the most vulnerable to water and nitrogen losses.

Nitrogen transformations can be effectively managed by the entire set of management practices, designed to increase nitrogen use efficiency (NUE) and to decrease surface and groundwater pollution. The global fertilizer industry-led "4-R Nutrient Stewardship" concept based on scientific understanding of applying the Right source of nutrients at the Right rate, Right time, and Right place (Snyder et al., 2014) needs to be optimized at local and regional scales by engagement of many partners including farmers, crop advisers, scientists, policymakers, consumers, and the general public (Bruulsema et al., 2009). Techniques for improving NUE include controlled-release fertilizers and urease and nitrification inhibitors, improved soil and plant testing to match nutrient applications with crop demands, use of winter cover crops, adoption of precision agriculture technologies, improved irrigation management and increasing availability of decision support tools for farmers and crop advisors (Davidson et al., 2015).

According to the vulnerability maps presented above and current land use and conservation practices, the production and yields increases in Pančevo agriculture should proceed respecting the following priority nitrogen $\mathrm{BMPs}^{20}$ to improve NUE and reduce nitrate leaching and runoff:

(i) Determined closed periods for use of fertilizers, rules for land application under certain conditions (water-saturated, frozen or snow-covered ground, near water courses, on sloping ground) and balanced fertilization (using soil testing, fertilizer plan and records on fertilizer use, real-time nitrogensensors and variable rate controllers for precision fertilizing, ${ }^{21}$ controlledrelease fertilizers and nitrification inhibitors, split applications and maximum application standards, and farm nutrient management plan with specification of storage requirements for livestock manure).

(ii) Optimized agricultural production structure and irrigation methods as a function of soil characteristics (expansion of orchards and vineyards on northeast upland sandy soils, use of precision irrigation scheduling and drip irrigation ${ }^{22}$ for row crops and tree plantations, crop rotation and cultivation of crop residues and $\mathrm{N}$-fixing and cover crops for soil winter cover, particularly on sloping ground).

(iii) On the area with higher slopes it is also necessary to apply contour ploughing, promote conservation tillage and maintain cropland and riparian buffer strips to prevent water and nitrogen surface runoff.

20 BMPs for $\mathrm{N}$ fertilizers and livestock manure utilisation.

21 With a 'real-time' nitrogen-sensor it is possible to apply fertilizer precisely and automatically at different rates in a field according to the natural variation of nutrients that are already in the soil (CEMA, 2013).

22 Proper irrigation scheduling, coupled with efficient irrigation systems is an important BMP for improving water use efficiency (WUE) and reduce nitrate leaching (Bauder et al., 2017; Perea et al., 2017; Popović, Ugrenović, 2015). 
The EU Nitrate Directive has introduced the obligations of identifying polluted waters or waters at risk of pollution, designating land areas which drain into these waters (nitrate vulnerable zones - NVZs) and establishing the Code of Good Agricultural Practice (GAP) to be implemented by farmers on a voluntary basis and an action programme of mandatory measures for farmers within NVZs. Well-tailored, site-specific nitrogen BMPs based on the LOS analysis can significantly improve the quality of ND action programmes.

\section{Policy and incentives}

Development of criteria for NVZ designation and identification of agricultural land with significant contribution to $\mathrm{N}$ pollution, delineation of these zones and a catalogization of best agricultural practices to control nitrate pollution were the topics of the ENVAP II project, realized during 2014-2016 by the Ministry of Agriculture and Environmental Protection of the Republic of Serbia within the framework of cooperation with the Swedish Environmental Protection Agency. Main results of the project were the proposals of criteria for NVZs designation, NVZ designation and delineation and the Code of Good Agricultural Practice ${ }^{23}$. These proposals are the subjects of revision within IPA 2013 project "Further implementation of the National Environmental Approximation Strategy", within which the Specific Implementation Plan for the Nitrates Directive will be developed (The Government of the Republic of Serbia, 2018).

Establishment of the legal basis for determination of NVZ designation criteria, NVZ designation and delineation, adoption of action programmes of mandatory measures to protect NVZs, adoption of the Code of Good Agricultural Practice and determination of monitoring programme for evaluating the results of action programmes and review the document on determining the vulnerable zones, was carried out by the Law on Amendments to the Law on Waters (OG RS, 101/2016).

National Programme for the Adoption of the Acquis - NPAA (Third Revision, 2018) stipulates for the period 2018-2021: development of Specific Implementation Plan for the Nitrates Directive, designation of NVZs and adoption of the Code of GAP by the end of 2019 and development of Action Programs for implementation of measures to protect NVZs by the end of 2021 (two years after NVZ designation). Inclusion of agricultural advisory services at the local level in the process of farmer training for implementation of the GAP (and later also measures established by action programs) in NVZ is planned for 2019 (The Government of the Republic of Serbia, 2018).

Implementation of the EU Nitrate Directive requires considerable investments ${ }^{24}$, including IPARD funds. Some investments for reduction of nitrogen (and phosphorus) flows into waters were realized in Serbia within the World Bank-led GEF Danube River Enterprise Pollution Reduction - DREPR project (2005-2011). The cost of the project

23 According to this project proposal, NVZs would cover approximately $49 \%$ of the territory of Serbia (Belgrade Chamber of Commerce, 2016).

24 Capital investments for reducing water pollution from agriculture are estimated at $€ 0.9$ billion (OG RS, 80/2011). 
was US\$ 20.73 million, of which US\$ 18.16 million was spent on nutrient reduction investments $^{25}$ (The World Bank, 2012).

IPARD II (2014-2020) financial support is available within the Republic of Serbia IPARD Programme for 2014-2020 to large and medium-sized livestock farms for investments in storage facilities and equipment for manure management and to medium-sized field crop farms to purchase machinery for soil fertilization, while state financial support schemes for the mentioned purposes are reserved for small farms in these sectors (MAEP, 2014b).

\section{Conclusion}

Extensive use of nitrogen fertilizers and livestock manure in crop production and improper livestock manure management can severely deteriorate water quality and ecosystem performances. Effective nitrogen management can optimize crop yields and increase profitability while minimizing nitrogen losses. Knowledge of nitrogen flows is essential for designing management guidelines to minimize surface and groundwater pollution. LOS indices, i.e. vulnerability maps based on these indices, developed to classify the intrinsic vulnerability of the topsoil to water and nitrogen losses via percolation and runoff and applied in the City of Pančevo case study, pointed to the northeast part of the City of Pančevo territory as the most vulnerable to water and nitrogen losses. This is very important information that allows optimal selection of nitrogen BMPs adjusted to local climate, topography and soil properties. The identification of agricultural lands with significant contribution to $\mathrm{N}$ pollution, delineation of these zones and a catalogization of best agricultural practices to control nitrate pollution are the main tasks within the EU Nitrate directive transposition, which is ongoing in the Republic of Serbia and the research presented above can contribute to these efforts.

\section{Acknowledgements}

Article is part of project III 46006 Sustainable agriculture and rural development in the function of accomplishing strategic objectives of the Republic of Serbia in the Danube region, financed by the Ministry of Education, Science and Technological Development of the Republic of Serbia in the period 2011-2018.

\section{Conflict of interests}

The authors declare no conflict of interest.

25 Storage facilities and equipment for manure management were financed in 105 farms. The annual reduction in nitrogen pollution flows from these farms is estimated to be $44 \%$. 


\section{References}

1. Amdur, M. O., Doull, J., Klassen, C. D. (Eds.). (1991). Casarett and Doull's toxicology. The Basic Science of Poisons. 4th edition. New York, USA: Pergamon Press.

2. Arampatzis, S., Tagarakis, A., Kazakis, N., Zioga, D., Bolognesi, S., \& Carraro, G. (2012). Development of Transnational Strategy for the Integrated Water Management in Agriculture: technical recommendations. EU-WATER Project: WP4 Common strategy and local adaptations. Retrieved from http://www.euwater.eu/images/ WP4\%20strategy\%20total\%20 final\%20deliver 22.04.2012. pdf (March 12, 2017).

3. Aschonitis, V. G., \& Mastrocicco, M. (2017). Intrinsic Vulnerability of Agricultural Lands to Water and Nitrogen Losses. In Proceeding of International Scientific Conference Sustainable Agriculture and Rural Development in terms of the Republic of Serbia Strategic Goals Realization within the Danube Region - Development and Application of Clean Technology in Agriculture. Institute of Agricultural Economics Belgrade, Serbia, 89-106.

4. Aschonitis, V. G., Castaldelli, G., Colombani, N., \& Mastrocicco, M. (2016). A combined methodology to assess the intrinsic vulnerability of aquifers to pollution from agrochemicals. Arabian Journal of Geosciences, 9(7): 503. doi:10.1007/ s12517-016-2527-2.

5. Aschonitis, V.G., Salemi, E., Colombani, N., Castaldelli, G., \& Mastrocicco, M. (2013). Formulation of Indices to Describe Intrinsic Nitrogen Transformation Rates for the Implementation of Best Management Practices in Agricultural Lands. Water, Air, \& Soil Pollution, 224(3):1489, doi :10.1007/s11270-013-1489-1.

6. Aschonitis, V.G., Mastrocicco, M., Colombani, N., Salemi, E., Kazakis, N., Voudouris, K., \& Castaldelli, G. (2012). Assessment of the Intrinsic Vulnerability of Agricultural Land to Water and Nitrogen Losses via Deterministic Approach and Regression Analysis. Water, Air, \& Soil Pollution, 223(4), 1605-1614, DOI: 10.1007/s11270-011-0968-5.

7. Bauder, T. A., Waskom, R. M., \& Wardle, E. M. (2017). Agricultural Nitrogen Management. Best Management Practices. Bulletin XCM-172: Colorado State University. Retrieved from http://extension.colostate.edu/docs/pubs/crops/ xcm172.pdf (March 22, 2017).

8. Beaulieu, J. J., Tank, J. L., Hamilton, S. K., Wollheim, W. M., Hall, R. O., Mulholland, P. J., ... Thomas, S. M. (2011). Nitrous oxide emission from denitrification in stream and river networks. Proceedings of the National Academy of Sciences of the United States of America, 108(1), 214-219. http://doi. org/10.1073/ pnas.1011464108. 
9. Belgrade Chamber of Commerce. (2016). Presented results of the project "Proposal for determining the vulnerable zones and sensitive areas in accordance with Nitrates Directive and the UWWTD”. [In Serbian: Privredna komora Beograda (2016). Prezentovani rezultati projekta "Predlog za određivanje ranjivih zona i osetljivih područja u skladu sa Nitratnom direktivom i Direktivom o komunalnim otpadnim vodama"]. Retrieved from http://www.kombeg. org.rs/aktivnosti/c tehno/Detaljnije. aspx?veza=19209 (February 18, 2017).

10. Bouraoui, F., Grizzetti, B., \& Aloe, A. (2009). Nutrient discharge from rivers to seas for year 2000. JRC Scientific and Technical Reports. Luxembourg.

11. Böhlke, J. K. (2002). Groundwater recharge and agricultural contamination. Hydrogeology Journal, 10(1), 153-179, doi: 10.1007/s10040-001-0183-3.

12. Bruulsema, T., Lemunyon, J., \& Herz, B. (2009). Know your fertilizer rights. Crops Soils, 42(2), 13-18.

13. Carpenter, S. R., Caraco, N. F., Correll, D. L., Howarth, R. W., Sharpley, A. N., \& Smith, V. H. (1998). Nonpoint pollution of surface waters with phosphorus and nitrogen. Ecological Applications 8(3), 559-568.

14. CEMA-EuropeanAgricultural Machinery.(2013). Smart equipment for sustainable agriculture. Precision Farming: producing more with less. The CEMA Exhibition, European Parliament, 14-18 October 2013. Retrieved from http://cema-agri.org/ sites/default/files/Smart $\% 20$ equipment $\% 20$ for $\% 20$ sustainable $\% 20$ agriculture. pdf (March 12, 2017).

15. Chislock, M. F., Doster, E., Zitomer, R. A. \& Wilson, A. E. (2013). Eutrophication: Causes, Consequences, and Controls in Aquatic Ecosystems. Nature Education Knowledge 4(4):10.

16. Cvijanović, D., Vuković, P., \& Subić, J. (Eds.). (2012). EU.WATER Transnational integrated management of water resources in agriculture for the European water emergency control - Handbook of Pančevo city (Serbia). Layman's Report. Belgrade: Institute of Agricultural Economics. Retrieved from http://www.euwater.eu/images/ Laymans $\% 20$ report $\% 20$-20Finale $\% 20$ April $\% 202012 \% 20-\% 20$ IAE\%20 Belgrade-20.04.2012..pdf (March 12, 2017).

17. Davidson, E. A., Suddick, E. C., Rice, C. W., \& Prokopy, L. S. (2015). More Food, Low Pollution (Mo Fo Lo Po): A Grand Challenge for the 21st Century. Journal of Environmental Quality, 44(2), 305-311. doi:10.2134/jeq2015.02.0078.

18. Džamić, R. (1966). Handbook for soil testing. Soil testing chemical methods. Belgrade [In Serbian: Džamić, R. (1966). Priručnik za ispitivanje zemljišta. Hemijske metode ispitivanja zemljišta].

19. European Commission. (2013). Report from the Commission to the Council and the European Parliament on the implementation of Council Directive 91/676/EEC concerning the protection of waters against pollution caused by nitrates from agricultural sources based on Member State reports for the period 2008-2011. Brussels, COM (2013) 683 final. 
20. FAO. (2014). FAO Statistical Yearbook 2014. Europe and Central Asia Food and Agriculture. Budapest: FAO.

21. Haller, L., McCarthy, P., O’Brien, T., Riehle, J., \& Stuhldreher, T. (2013). Nitrate pollution of groundwater. Alpha Water Systems INC. Retrieved from http://www. reopure.com/nitratinfo.html (February 11, 2017).

22. International Commission for the Protection of the Danube River - ICPDR. (2015). The Danube River Basin District Management Plan. Part A-Basin-wide overview. Update 2015. Vienna, Austria: ICPDR.

23. Knisel W.G., \& Davis F.M. (2000). GLEAMS, Groundwater loading effects from agricultural management systems V3.0. SEWRL-WGK/FMD-050199, U.S.D.A., Tifton, Georgia.

24. Leonard, R. A., Knisel, W. G., \& Still, D. A. (1987). GLEAMS: Groundwater Loading Effects of Agricultural Management Systems. Transactions of the American Society of Agricultural Engineers, 30(5), 1403-1418.

25. Leone, A., Ripa, M. N., Uricchio, V., Deák, J., \& Vargay, Z. (2009). Vulnerability and risk evaluation of agricultural nitrogen pollution for Hungary's main aquifer using DRASTIC and GLEAMS models. Journal of Environmental Management 90(10), 2969-2978, DOI: 10.1016/j.jenvman. 2007. 08.009.

26. Manos, B.D., Papathanasiou, J., Bournaris, T., \& Voudouris, K. (2010). A DSS for sustainable development and environmental protection of agricultural regions. Environmental Monitoring and Assessment, 164(1), 43-52, doi: 10.1007/s10661009-0873-1.

27. Ministry of Agriculture and Environmental Protection of the Republic of Serbia MAEP. (2014a). Water Management Plan for the Danube River Basin 2015-2021. Belgrade: Institute for Water Management "Jaroslav Černi”. Draft document. [In Serbian: Министарство пољопривреде и заштите животне средине. (2014a). Нацрт плана управљања водама за слив реке Дунав].

28. Ministry of Agriculture and Environmental Protection of the Republic of Serbia MAEP. (2014b). Republic of Serbia IPARD Programme for 2014-2020. Belgrade.

29. Nolan, B.T., Hitt, K.J., \& Ruddy, B.C.(2002). Probability of nitrate contamination of recently recharged groundwater in the conterminous United States. Environmental science \& technology, 36(10), 2138-2145.

30. Official Gazette of the Republic of Serbia, no 101/2016. Law on Amendments to the Law on Waters [In Serbian: Службени гласник PC, бр. 101/2016. Закон о изменама и допунама Закона о водама].

31. Official Gazette of the Republic of Serbia, no 80/2011. National Environmental Approximation Strategy for the Republic of Serbia [In Serbian: Службени гласник PC, бр. 80/2011. Национална стратегија за апроксимацију у области животне средине за Републику Србију]. 
32. Official Journal of the European Communities (1991). Council Directive of the 12 December 1991 concerning the protection of waters against pollution caused by nitrates from agricultural sources (91/676/EEC).

33. Ongley, E. D. (1996). Control of water pollution by agriculture. FAO Irrigation and Drainage Paper 55. Rome: FAO.

34. Osterberg, D., \& Wallinga, D. (2004). Addressing Externalities From Swine Production to Reduce Public Health and Environmental Impacts. American Journal of Public Health, 94(10), 1703-1708, doi: 10.2105/AJPH.94.10.1703.

35. Paerl, H. W., \& Paul, V. J. (2012). Climate change: links to global expansion of harmful cyanobacteria. Water Research 46, 1349-1363.

36. Paerl, H. W., Hall, N. S., \& Calandrino, E. S. (2011). Controlling harmful cyanobacterial blooms in a world experiencing anthropogenic and climaticinduced change. Science of the Total Environment 409, 1739-1745.

37. Perea, R. G., García, I. F., Arroyo, M. M., Díaz, J. R., Poyato, E. C., \& Montesinos, P. (2017). Multiplatform application for precision irrigation scheduling in strawberries. Agricultural Water Management, 183, 194-201.

38. Popović, V., \& Ugrenović, V. (2015). Improved Irrigation Management for Sustainable Agriculture. In G. Popescu, A. Jean-Vasile (Eds.), Agricultural Management Strategies in a Changing Economy (pp. 357-378). Hershey, Pennsylvania (USA): IGI Global.

39. Puckett, L. J., Tesoriero, A. J., \& Dubrovsky, N. M. (2011). Nitrogen Contamination of Surficial Aquifers - A Growing Legacy. Environmental Science \& Technology, 45(3), 839-844, DOI: 10.1021/es 1038358.

40. Sahoo, P.K., Kim, K., \& Powell, M.A. (2016). Managing Groundwater Nitrate Contamination from Livestock Farms: Implication for Nitrate Management Guidelines. Current Pollution Reports, 2(3), 178-187, doi:10.1007/s40726016-0033-5.

41. Sandstedt, C. A. (1990). Nitrates: Sources and their Effects upon Humans and Livestock. Washington, DC: The American University.

42. Schindler, D. W. (1974). Eutrophication and Recovery in Experimental Lakes: Implications for Lake Management. Science, New Series, 184(4139), 897-899.

43. Seitzinger, S.P., Harrison, J.A., Böhlke, J.K., Bouwman, A.F., Lowrance, R., Peterson, B. ... Drecht, G.V. (2006). Denitrification across landscapes and waterscapes: a synthes. Ecological Applications, 16(6), 2064-2090, doi: 10.1890/ 1051-0761(2006)016 [2064:DALAWA]2.0.CO;2.

44. Serbian Environmental Protection Agency - SEPA. (2015). Report on the State of Environment in the Republic of Serbia for 2014. Belgrade [In Serbian: Агенција за заштиту животне средине. (2014). Извештај о стању животне средине у Републици Србији за 2014. годину]. 
45. Smith, V. H., \& Schindler, D. W. (2009). Eutrophication science: where do we go from here? Trends in Ecology and Evolution 24, 201-207.

46. Snyder, C.S., Davidson, E.A., Smith, P. \& Venterea, R.T. (2014). Agriculture: Sustainable crop and animal production to help mitigate nitrous oxide emissions. Current Opinion in Environmental Sustainability, 9-10, 46-54, http://dx.doi.org/ 10.1016/j.cosust.2014.07.005.

47. Spalding, R. F., \& Exner, M. E. (1993). Occurrence of nitrate in groundwater - a review. Journal of Environmental Quality, 22(3), 392-402, doi: 10.2134/jeq1993. $00472425002200030002 x$.

48. Statistical Office of the Republic of Serbia. (2015). Census of Agriculture 2012. Database at the level of settlements [In Serbian: Републички завод за статистику Србије. (2015). Попис пољопривреде 2012. База података на нивоу насеља]. Retrieved from http://popispoljoprivrede.stat.rs/?page id=6221 (December 22, 2016).

49. Statistical Office of the Republic of Serbia. (2014). 2011 Census of Population, Households and Dwellings in the Republic of Serbia: Comparative overview of the number of population 1948-2011. [In Serbian: Републички завод за статистику Србије. (2014). Попис становништва, домаћинстава и станова 2011. у Републици Србији: Упоредни преглед броја становника 1948-2011].

50. The Government of the Republic of Serbia. (2018). National Programme for the adoption of the EU acquis. Third Revision. [In Serbian: Влада Републике Србије. (2018). Национални програм за усвајање правних тековина Европске уније. Treća ревизија]. Retrieved from http://www.mei.gov.rs/upload/documents/ nacionalna dokumenta/npaa/npaa 2018 2021.pdf (March 12, 2018).

51. The World Bank. (2012). Better agricultural practices in Serbia for a cleaner Danube river. Results profile. Washington, D.C.: World Bank Group.

52. Van Drecht, G., Bouwman, A. F., Knoop, J. M., Beusen, A. H. W., \& Meinardi, C. R. (2003). Global modeling of the fate of nitrogen from point and nonpoint sources in soils, groundwater, and surface water. Global Biogeochemical Cycles, 17(4), 1115, doi: 10.1029/2003GB002060.

53. Welch, H. L., Green, C. T., \& Coupe, R. H. (2011). The fate and transport of nitrate in shallow groundwater in northwestern Mississippi, USA. Hydrogeology Journal, 19(6), 1239-1252, doi: 10.1007/s10040-011-0748-8. 